\title{
A dança «en-cena» o outro: prerrogativas para uma educação estética através do processo criativo
}

\author{
Flávio Soares Alves *
}

\begin{abstract}
Resumo: A dança instala no corpo uma outra cena de sentidos que potencializa a ação criativa, assim, quando o corpo dança, sua percepção é aguçada em direção a estados alterados da consciência. Neste nível perceptível, instalado em meio ao processo criativo, técnica (a competência) e liberdade (a performance) se relacionam, e criam, como efeito, a dança. A partir desta evidência, que aqui será sustentada segundo um cruzamento de leituras entre a psicanálise e a filosofia, lanço-me a uma reflexão sobre a percepção corporal na dança, na tentativa de situar a atuação criativa. Assim, abro um caminho para entender o processo criativo como campo de sensibilização corporal, a partir do qual a intervenção educativa é efetivada no corpo.
\end{abstract}

Palavras-chave: Dança. Cinésica. Psicanálise. Criatividade.

\section{INTRODUÇÃo}

Alguma vez, leitor gentil, já lhe aconteceu viver
uma experiência que dominasse completamente seu
peito, seus pensamentos e sua mente, fazendo com
que esquecesse tudo o mais? Nesse caso, sentiria
um fermentar e ferver dentro de você, o sangue percor-
reria suas veias qual brasa ardente, colorindo viva-
mente suas faces. Seu olhar seria tão estranho como
se quisesse apreender, no espaço vazio, formas invi-
síveis a qualquer outro olho, enquanto as palavras
se desfariam em lúgubres suspiros Aí os amigos
indagariam: "Como vai meu caro?"- E então você
haveria de querer descrever a visão interior com
todas as suas cores brilhantes, as sombras e as luzes,
e você haveria de extenuar-se na procura das palavras

* Graduado em Educação Física (Licenciatura) pela UNESP. Mestre em Artes pela Unicamp Cursando Doutorado em Educação Física - Área de concentração: Pedagogia do Movimento Humano - na Escola de Educação Física e Esportes da USP. São Paulo, SP, Brasil. E-mail: flavio.salves@usp.br 
para apenas começar a descrever o sucedido [...] (HOFFMAN, apud CESAROTTO, 1996, p. 29$30)$.

Esse trecho extraído do conto "O homem de areia", de Hoffmann, bem poderia fazer referência à dança. Trata-se, no entanto, de uma introdução narrativa que prepara o leitor para um conto fantástico. Há quem diga que a dança também é fantástica. $\mathrm{O}$ estado corporal de um artista à beira do processo criativo, ou de um espectador, mergulhado na emanação energética que o prende à contemplação de uma atuação artístico-corporal é um estado fantástico.

A experiência fantástica de dançar é um momento de insólita percepção. Nela, é como se a unidade do Eu se evadisse revelando, na vazão deste egresso fugaz, a atuação de um corpo Outro ${ }^{1}$ por ele próprio desconhecido. Daí seu caráter inconcebível na concretude real.

Não falo aqui de uma dança específica, mas do ato de se entregar à dança, ou seja, à espontaneidade da atuação corporal. Através deste deslocamento, o corpo se coloca à disposição em relação à abertura da profundidade de si.

O artista pode achar que domina a própria atuação, no entanto, aquilo que emana de sua dança é sempre mais do que a percepção calculada desta atuação sob as vias do entendimento, o que faz despontar a dúvida: Quem dança?

Pode parecer equívoco atribuir ao Outro a atuação artística e não ao Eu, mas o leitor dançarino há de convir comigo que na dança o corpo excede a seus limites, numa estranha amplitude de atuação. Este excesso é o que vaza da unidade de ser um. É este excesso o que sobra do contorno da unidade. É o gozo, é o Outro.

Até aqui, arrisquei-me à observação de alguns conceitos que podem parecer estranhos ao âmbito da Educação Física. Assim, beiro à desagradável injunção de passar por incompreendido, portanto, é preciso cuidado, sobretudo na forma de olhar estas considerações,

${ }^{1} \mathrm{O}$ Outro no Eu diz respeito à alteridade radical, que não se confunde com o semelhante. Corresponde ao registro simbólico, no qual se desenvolve a Linguagem, ou o Inconsciente (LACAN, 1998).

Wovimento, Porto Alegre, v. 15, n. 03, p. 333-354, julho/setembro de 2009. 
para extrair delas um sentido que instigue a leitura do texto e introduza o leitor na perspectiva que o autor assume.

Pensando neste cuidado, é preciso deixar claro, primeiramente, o entendimento que norteia o ponto de vista do sujeito clássico, uma vez que é este entendimento que a ciência moderna assume como referencial, por meio do qual se constitui a ordem do pensamento racional.

Descartes instala sobre o corpo a figura do sujeito universal enquadrando, nas formas da ciência moderna, o dualismo platônico. Sobre esse enquadramento, Descartes pergunta sobre o que é possível saber, uma vez instalado definitivamente a fratura cartesiana na óptica do pensamento. Assim, distingue-se o possível saber - circunscrito nos limites da representação - daquilo que não se pode reduzir no campo do conhecimento.

O célebre aforismo cartesiano Penso, logo existo deixa claro o ponto de vista da ciência moderna. Sob esta perspectiva, o sujeito deve saber que não compreende a experiência em sua totalidade para poder ser um sujeito do saber. Assim, é possível lidar com as funções que operam na faculdade do entendimento, convencionando-se que não existe entre elas uma indeterminação (GAUFEY, 1996, p. 22).

Visto dessa forma, não cabe observar a dança como uma experiência fantástica, uma vez que as vias desse entendimento não alcançam, ou melhor, não admitem esta adjetivação, pois ela não se sustenta no real como evidência passível de determinação (ALVES, 2006).

Neste nível de verificação, o pensamento racional circunscreve a experiência segundo uma estrutura de entendimento que só apreende aquilo que da experiência admite determinação. Assim, à moda cartesiana, o saber é condicionado às prerrogativas de um entendimento lógico que descarta tudo que a ele - ao entendimento - se mostra impalpável, como a experiência fantástica, por exemplo. Desta maneira, é possível tomar a dança como objeto de estudo e suspendêla frente ao pesquisador como recurso metodológico que garante a objetividade analítica. Todavia, aí, falta a magia, a espontaneidade, a fantasia, justamente devido à essência inapreensível dessas evidências (ALVES, 2006).

Movimento, Porto Alegre, v. 15, n. 03, p. 333-354, julho/setembro de 2009. 
O achado do sujeito do inconsciente deu novas perspectivas críticas a esta construção hegemônica do saber. A releitura cartesiana feita por Freud resgata a noção de sujeito, instalando uma discussão bastante intrigante que será fundamental para entender o deslocamento analítico proposto neste texto. Segundo Freud, para além de um sujeito que afirma: Penso, logo existo - condicionando, assim, sua existência a um movimento de pensamento logicamente estruturado (sustentado sob a égide de uma autoria que chama a responsabilidade das experiências vividas na circunscrição do Eu) - há um outro movimento de pensamento que constitui o "Eu" nos interstícios desta unidade possível de se inscrever como ser. É neste enquadramento que Freud introduz o conceito de sujeito do inconsciente, para mostrar que também há pensamento, sem a presença de um Eu que cogita (GAUFEY, 1996, p. 11). É neste engodo, isto é, neste pensamento forjado ${ }^{2}$, que se observa o Outro em cena, dando uma nova perspectiva de verificação da dança.

Se o sujeito clássico reclama pela unidade do ser, a dança não se encontra aí, senão na sua redução especular, pois, na unidade, a dança é o relato uníssono de um Eu afirmativo que toma para si a autoria da atuação.

Não se trata aqui, caro leitor, de reafirmar a dualidade platônica, mas alçar-se sobre esta fratura como recurso pertinente à instalação de uma outra cena, que potencialize a ação criativa e não o que dela se especula. Este desvio consiste em amainar as pretensões coercivas do Ego, para que a espontaneidade possa se ver livre na criação.

Ora, se é na intensidade de sentidos em curso na vazão da espontaneidade que o corpo se abre à sua dimensão criativa de ser, não estaria aí o grande gerador de ensino e aprendizado, uma vez que é somente aí que o corpo se deixa afetar em profundidade? A que ponto os processo de criação da dança podem dialogar com os

\footnotetext{
${ }^{2}$ Freud reduz estas impressões na ordem do sintoma (GAUFEY, 1996, p. 11). Esta verificação não interessa para este ensaio. Foi em Freud que o achado do sujeito do inconsciente teve sua expressão inaugural, todavia, são os desdobramentos que daí decorreram - revelando novas dimensões sobre o conceito de inconsciente - que inspira a um cruzamento de leituras atento aos objetivos deste estudo.

Movimento, Porto Alegre, v. 15, n. 03, p. 333-354, julho/setembro de 2009.
} 
processos de intervenção educacional no corpo? Para responder essa pergunta, deslocamos nossa investigação para a análise da percepção corporal em meio à dança. É aí, na regência do Outro, que o processo criativo apresenta prerrogativas de intervenção, através das quais torna-se possível desenvolver uma educação estética.

Quem dança em mim quando danço? Certamente eu mesmo, só que em estados alterados da percepção. O objetivo deste texto é compreender esta alteração perceptiva como indício de um outro olhar sobre o corpo na educação.

\section{ESTADOS ALTERADOS DA CONSCIÊNCIA}

A dança arrebata a ação motora e transforma sua efetuação numa inscrição vibrante que irrompe do corpo, sem que esse tenha um monitoramento consciente incisivo sobre a expressão.

Em meio à trajetória gestual no espaço, o corpo comprime o tempo, pulverizando seu esquadrinhamento simétrico e amplia a dimensão do espaço. Assim, potencializa não o tempo instituído, mas a sua re-criação, dando visibilidade à outra temporalidade. Neste deslocamento, o sujeito-atuante altera os estados da consciência, desbravando os canais perceptivos, para além dos condicionamentos e determinações da consciência cotidiana.

O estado alterado da consciência é aquele em que perdemos a noção do tempo (SOARES, 2000). O processo de criação da dança acontece em estados alterados da consciência. Esta alteração permite a vazão criativa e a representação ativa dos gestos expressivos. Sem ela, a representação se cristaliza e o repertório coreográfico se reduz a uma articulação motora seriada, pois se inscreve determinada, no enquadramento linear do espaço e do tempo.

A espontaneidade do corpo criativo, no entanto, não permite que a arte sucumba aos imperativos da consciência cotidiana. Assim, quando o corpo se predispõe a arte, a consciência é deslocada para outros canais de expressão. É como mergulhar dentro de si mesmo e perceber que, no âmago da interioridade, o Eu não é mais o mesmo,

Movimento, Porto Alegre, v. 15, n. 03, p. 333-354, julho/setembro de 2009. 
mas um desconhecido que atua à revelia dele mesmo. Nesta alteração perceptiva, o sujeito atua num estado de transe ${ }^{3}$.

O transe é um estado alterado da consciência provocado por um esforço de concentração que vai divergindo simetricamente dentro de si mesmo e se expandindo sem perder o elo com o esforço de concentração que lhe deu origem. No transe, o olhar penetra além do consciente, num plano exterior e fora da órbita do controle, eclipsando o $\mathrm{Eu}$ - espaço virtual do narcisismo - para adotar diferentes pontos de vista, dobrando-se perante uma interioridade estranha. Nesta outra abordagem perceptiva, a superfície da consciência se dilui e mostra um Outro atuante constitutivo deste mesmo Eu que delibera (CESAROTTO, 1996).

Qualquer esforço racional em situar esta sintonia desloca-a, fazendo esvaecer sua essência inapreensível. O Eu se dá conta de que não outro, senão ele próprio atua e reclama pela autoria da performance, por isso, o transe permanece não localizável. Nada garante sua vazão, só a predisposição espontânea que dá visibilidade a esta dimensão perceptiva. A promoção deste estado se dá no desarranjo da consciência, na ampliação de um estado de concentração que esvazia o Eu dos imperativos da consciência, liberando-o para uma outra dimensão experimental.

O esvaziamento pode ser provocado através de exercícios que possibilitem esse deslocamento perceptivo. É aí que a atuação estética se aproxima de uma atuação educativa, pois, através desses exercícios, o corpo vai aprofundando seu campo de sensibilização e usando suas habilidades e capacidades físicas em função de uma projeção original de si. No curso dessa projeção, o corpo vai constituindo sua técnica corporal e tecendo sua linguagem. Todavia, tal processo só se faz quando o laboratório de criação abre caminho para a sensibilização corporal e este trabalho só é alcançado em estados alterados da consciência. É aí que reina o processamento criativo.

\footnotetext{
${ }^{3}$ A palavra transe vem do latim transitus que quer dizer "passagem". Segundo a análise de Devereux, sobre o Xamanismo, o transe inter-relaciona os níveis psíquico e físico, liberando energias reprimidas e reintegrando o homem com uma dimensão divina (DEVEREUX, 1993, p. 129).

Movimento, Porto Alegre, v. 15, n. 03, p. 333-354, julho/setembro de 2009.
} 
Para chegar aos domínios deste processamento, grupos de experimentação corporal desenvolvem experiências coletivas que instalam no corpo um caminho de sensibilização. Este método é chamado de Instalação, e consiste em instalar no corpo experiências rituais que se repetem a cada início de trabalho, para aclamar os estados energéticos corporais, gerando um campo magnético no corpo, que favoreça a alteração perceptiva, com isso, o corpo se torna mais receptivo à estimulação sensível.

O trabalho coletivo favorece este deslocamento, pois a experiência relacional gera uma energia coletiva e cria um campo unificado que envolve todos num mesmo limiar de percepção. A experiência coletiva, portanto, amplia o potencial criativo do corpo. O Outro em mim, em contato com a alteridade dos outros na instalação amplia as possibilidades relacionais. $\mathrm{O}$ transe esvazia o sujeito das condições que orientam a consciência cotidiana, potencializando outras maneiras de ser na coletividade, ampliando o trabalho criativo, em detrimento da falência dos imperativos sociais, na vigência da instalação.

A Instalação é fundamental para predispor o sujeito a esta atuação, que se inscreve na suspensão da existência consciente, na vazão do estado de transe. Nesta outra abordagem do ser, o Eu descobre que não está só dentro de si e, em meio a um e outro esforço de se identificar, estranha a si mesmo na ação de outros "Eus" emersos da obscuridade da inconsciência.

$\mathrm{O}$ ato performativo ${ }^{4}$ surge neste nível de percepção. No momento em que a dança está em processo, o contorno da composição gestual vai se delineando neste movimento performático e produzindo o repertório coreográfico.

\section{ARRANJO EM DESARRANJO}

O processo criativo é essencialmente performativo. A apresentação desse processo como produção define o grau de

\footnotetext{
${ }^{4}$ Referência à arte de Performance, na qual o artista desloca o valor da obra para o momento de criação, rompendo com a representação elaborada e valorizando a expressão cênica em sua

Wovimento, Porto Alegre, v. 15, n. 03, p. 333-354, julho/setembro de 2009.
} 
representação ${ }^{5}$ ativa da composição. Quanto mais preocupado com a forma, nas suas dimensões de simetria no tempo e no espaço, mais cristalizada a atuação se mostra. Mesmo aí, o momento de apresentação ainda recupera resquícios de uma intensidade espontânea, suscitada no momento da re-criação da composição pelo corpo - e é aí que esses resquícios fazem toda diferença.

O processo de construção gestual associa signos visuais, corporais e sonoros, numa composição não figurativa de impacto sensorial e emocional. Assim, a composição em dança está sempre sujeita à re-estruturação formal, pois, no momento da atuação, há uma tensão primordial que contrapõe a potência subjetiva e o esboço da composição gestual - em enunciação pelo artista.

O potencial subjetivo do intérprete tem o poder de re-figurar a interpretação, na medida em que coloca na atuação algo de si para animar a performance. Quanto maior a vazão deste potencial, mais aberta a obra aos desarranjos do Outro. Na medida em que o "Eu" se identifica com algumas frases de movimento - identificações imaginárias - a obra se torna mais fechada, mas mesmo aí ainda está suscetível a remanejamentos, pois, no momento em que a composição vem à tona, sua efetuação sai fora do controle racional e se entrega ao Outro.

A arte que se desenvolve por este processo é movida por um estímulo pulsante - e o pulsar aqui é uma imagem poética para o estímulo que instiga - celebrado como energia perene, em eterno retorno na vazão do processo criativo. Dependendo da maneira com a qual se quer organizar a performance, se intensifica ou se canaliza esta energia, estabelecendo parâmetros e limites a este vigor energético que sustenta a atuação.

relação espaço-temporal. Neste deslocamento, a arte só se justifica - e só significa - no momento de sua criação, isto é, o significante artístico só significa no contexto em que foi criado e este espaço tempo de criação justifica a obra (COHEN, 1989).

${ }^{5} \mathrm{O}$ termo representação, aqui empregado, remete à concepção de representação na arte de vanguarda, na qual não é possível conceber um sentido comum ao que representa, como objeto definido e idêntico ao referente. Tanto o atuante quanto os espectadores (os interpretantes) entram no processo de delimitação desta representação, mas cada qual na sua individualidade, interpretando o que o afeta na apresentação. Assim, entre a representação e o referente, há um terceiro, o interpretante, que constrói sentidos. Daí o caráter plural e não linear da representação, pois afeta a sensibilidade do interpretante, cada qual mediante seu ponto de sensibilização ( $C f$. BRITTO, 2001).

Wovimento, Porto Alegre, v. 15, n. 03, p. 333-354, julho/setembro de 2009. 
Todavia, seja qual for o nível de organização proposto, é o inconsciente que faz transparecer o sujeito do discurso (ou seja, aquele que atua) para além das identificações imaginárias, fazendo com que o sujeito apareça como efeito significante. Para Lacan, a significação está em constante deslocamento na ordem do significante. "O advento de sentido é efeito significante na linearidade do acontecimento" (LACAN, 1978, p. 233).

Não somos alheios, no entanto, aos nossos interesses, é exatamente na curiosidade que o desejo mais se evidencia (CESAROTTO, 1996). O que nos intima a criar, a curiosidade de fazer valer outra maneira, sempre outra a cada vez é o que dá dinâmica ao intangível desejo, fazendo-nos mergulhar na pesquisa de movimento e no processo criativo. É graças a este motim que nos mobilizamos à criação e não esgotamos as possibilidades numa única obra. A forma como se organiza a criação é um mero detalhe, desfigurado a cada nova proposta de trabalho.

O que é preciso deixar claro é que, não importa a maneira como se organiza a performance. Desde a mais estável composição, inscrita num linear metricamente codificado, até a performance mais aberta - em processo - a atuação sempre passa pelos crivos da eventualidade, que marca os desvios e a vontade de outras possibilidades expressivas. Eis aí a face subversiva da dança. É este arranjo (técnica) em desarranjo (liberdade) que dá luminosidade à performance, assegurando seu caráter fantástico.

\section{LIBERDADE E TÉCNICA}

O corpo treinado e habilidoso de um artista usa suas capacidades físicas e sua genialidade para operar as habilidades técnicas adquiridas a seu favor, não só para atestar sua competência técnica, mas para potencializar a vazão de sua capacidade criativa sobre este contorno sistêmico da motricidade - é o desempenho linguístico sobrepondo-se à competência linguística.

Trocando em miúdos, trata-se da relação entre liberdade e técnica. A liberdade é o que faz a técnica ser mais que mera proposição,

Movimento, Porto Alegre, v. 15, n. 03, p. 333-354, julho/setembro de 2009. 
é uma energia percebida no ato que aponta e mostra um fim provisório do gesto. A liberdade é o que permite o lapidar da técnica na impetuosidade do ato performático. Não há desempenho sem esta relação dual entre liberdade e técnica, pois é a tensão entre ambas que permite a evolução da performance.

É esta tensão que dá luminosidade ao gesto artístico, é o que sobra, para além das proposições técnicas, seja no nível estético de organização da performance (de estrutura narrativa e linear), seja no nível da presença cênica (de estrutura plural, em devir). A diferença entre ambas está na maneira como se desenvolvem os processos energéticos, responsáveis em tornar ativa esta tensão no gesto artístico.

Estes processos desestabilizam a função reguladora da consciência, abrindo caminho para a criação. Sua vazão brota da implicação entre a técnica e a liberdade fazendo alargar as margens da consciência, possibilitando o resgate de imagens ${ }^{6}$, imersas na obscuridade inconsciente, na efetuação da dança, ou seja, na tensão produtiva entre técnica e liberdade.

A tensão produzida pela atuação desses processos energéticos é sentida como algo que precisa ser descarregado. A dança é um canal de descarga dessa energia.

$\mathrm{O}$ artista atua na fruição energética que emana de suas ações corporais, preenchendo a composição a partir deste estímulo energético que lhe acomete e não a partir de algo imposto, exterior ao corpo.

Quando o artista organiza esta vazão de maneira linear e narrativa, mais estáveis os graus de atuação energética, acentuando os graus de monitoração consciente e mais previsível o desencadeamento da composição, ofuscando a natureza pulsante dessa emanação energética. Por outro lado, quando a performance se organiza de maneira plural, valorizando a atuação no espaço-tempo em que se dá como

\footnotetext{
${ }^{6} \mathrm{O}$ termo imagem está sendo utilizado segundo a leitura de Jung que toma o conceito de imagem verificando-o como possibilidade de ideias inatas, ou seja, como possibilidade de uma imagem arquetípica que irrompe dos processos inconscientes na atividade consciente no constante escoamento imagético dessa imagem primordial intangível (JUNG, 1991).

Movimento, Porto Alegre, v. 15, n. 03, p. 333-354, julho/setembro de 2009.
} 
evento, maior os riscos de remanejamento estrutural da composição, dando à performance seu caráter eminentemente processual.

De qualquer maneira, o estado de transe é mais intenso no processo de criação da dança, no momento em que o corpo se dá à imprevisibilidade da improvisação, do que no ato de sua apresentação performática, visto que os elos que agregam os gestos numa composição limitam sua capacidade representacional a uma ideia de organização (seja ela estética ou presença cênica).

Se esta apresentação é tomada como um trabalho em processo, mais ativos os graus de representação desta composição eventual. Todavia, mesmo a mais inédita e intensa apresentação gestual no processo de criação, não é mais do que um referente, ou seja, uma possibilidade de representação despertada num estado alterado de consciência. Cabe ao artista manter ativo este índice de representatividade, mantendo sua atuação artística o mais próximo possível do estado de transe. Quanto mais o corpo está receptivo ao estado de transe, mas facilmente está predisposto ao processo criativo.

A receptividade corporal favorece a instalação de uma outra cena no corpo, que atravessa as dimensões da fisicalidade e penetra no interior deste organismo funcional, verificando o que ali pulsa no limite entre o físico e o psíquico, despertando os domínios da inconsciência com os estímulos da instalação. Esta atuação se dá como efeito na relação entre o físico e o psíquico, entre a técnica e a liberdade, entre Dionísio e Apolo - sintetizando-se aqui, a tensão dual entre opostos que possibilita a expressão.

\section{ADINÂMICA DO DESEJO}

Os caminhos desta experiência forjada não são bem trilhados, pois são extensões da consciência embevecida, em busca dos processos inconscientes. O que aparece à razão é sempre efeito especular, isto é, configura-se como enunciado, em defasagem em relação à enunciação - dada no momento da atuação.

Segundo Lacan, a defasagem entre enunciado e enunciação vem do achado do sujeito do inconsciente que instala, necessariamente,

Movimento, Porto Alegre, v. 15, n. 03, p. 333-354, julho/setembro de 2009. 


\section{Antigor Originais}

Flávio Soares Alves

uma relação elíptica entre o $\mathrm{Eu}$ - lugar de desconhecimento - e o Outro - o atuante do discurso. Devido a esta injunção, o sujeito da enunciação pode faltar no enunciado, pois não cabe nesta síntese unívoca e especular (LACAN, 1978).

A enunciação corre por conta do inconsciente. A quem reclama a autoria da enunciação - o Eu - resta o retorno especular do discurso - o enunciado (Lacan, 1978). Daí a pergunta de Lacan: "Quem fala?" Esta resposta não poderia vir do Eu, "se ele não sabe o que diz, nem mesmo que fala" (LACAN, 1978, p. 283). O sujeito se eclipsa aí, sustentando-se entre a verdade a saber.

Ora, em que este saber psicanalítico pode contribuir na verificação sobre a dança? É bem verdade que a psicanálise lacaniana se fecha no âmbito da oralidade, todavia, é possível deslocar termos do discurso psicanalítico, num viés paralelo que traça relações de similaridade entre este discurso e a experiência da dança.

Para Lacan, a letra seria "esse suporte material que o discurso concreto empresta à linguagem" (LACAN, 1978, p. 225). Assim, se considerarmos a letra lacaniana neste deslocamento proposto, tal estrutura léxica pode ser interpretada como a célula de movimento, ou mesmo a frase que compõe a composição coreográfica e, a partir daí, dar sequência a este desdobramento.

Lá, onde o corpo se move, na fruição energética que o atravessa, se dá a enunciação. Quando uma composição gestual se esboça e se traça uma ligação, mais ou menos estável entre gestos, formando um linear coreográfico, o corpo memoriza esta inscrição num enunciado (cogito). A imagem/gesto memorizada tem a função da letra, é um processo de codificação que se estabelece para organizar a expressão.

A tendência do enunciado é se apagar, ou seja, o linear cinemático de uma composição, na ordem do enunciado, tende a uma estrutura ausente, desconexa, sem sentido. Para Lacan, a letra (o enunciado) mata, enquanto que o espírito - da ordem do inconsciente - vivifica (LACAN, 1978). A enunciação, portanto é quem reabilita o enunciado. Esta conversão entre enunciado e enunciação, no entanto, não pode ser controlada, pois corre por conta do trabalho inconsciente.

Movimento, Porto Alegre, v. 15, n. 03, p. 333-354, julho/setembro de 2009. 
Sintetiza-se aí a determinação do desejo, pois o sujeito anseia por diluir a defasagem entre enunciado e enunciação, alcançando, enfim, a verdade do sujeito e rompendo com a elipse que o mantém fadado a penar entre uma verdade por vir. Todavia, este fim não lhe é possível, pois não ele, mas Outro, faz retornar eternamente essa injunção, daí o constante escoamento de significantes que deem conta de uma necessidade de expressão sempre em pulsação.

\section{E POR FALAR EM DESEJO...}

A expressão do corpo em meio à dança, portanto, é um momento de insólita percepção de si, no qual o enunciado é anarquizado por sua própria enunciação, revelando, assim, a superdeterminação do inconsciente no momento da performance. $\mathrm{O}$ artista se coloca frente a si mesmo como num espelho, mas, na imagem, o corpo não se reconhece, embora esteja todo projetado na atuação artística ${ }^{7}$.

Esta assimetria impõe a diferença no registro do idêntico, forçando a alteridade. Por esse viés, aquilo que seria o mais conhecido e familiar, a própria imagem, vira estranho. Eis aí a dimensão do Outro, pois excede ao controle do Eu (CESAROTTO, 1996).

Desconhecendo a si mesmo, a dança se projeta na alçada de um Outro, do qual só é reconhecido o que se mostra semelhante a si. A sobra evade e é aí que a atuação artística se ilumina e encanta, surpreende, arrebata. Este registro revela a ação criativa, aquela que deixa seus sulcos no ar, na dinâmica da ação corporal no espaço.

Lá onde a dança é, no momento e que ainda não foi, no vacilo do entendimento deliberado e autocontrolado, em que de nada se especula, mas só se atua, é aí que o Outro toma as rédeas do corpo, usando os recursos simbólicos da dança para se mostrar no vigor mutante da atuação em si. ${ }^{7}$ A abordagem de Lacan sobre o "estágio do espelho", inspirou-me a esta paráfrase que tange
à dança. Para Lacan, o Eu constitui a si mesmo na imagem do próprio corpo, que se mostra ao
Eu como um outro semelhante a ele. O Eu se forma através da imagem do outro (o semelhante).
É o outro que possui sua imagem e não ele próprio, por isso a ideia de que o Eu é um lugar de
desconhecimento. Sintetiza-se aí o estágio do espelho (LACAN, 1978, p. 251-252; SANTAELLA,
2004 , p. 144-145).

Movimento, Porto Alegre, v. 15, n. 03, p. 333-354, julho/setembro de 2009. 
A natureza deste Outro, segundo a leitura freudiana, é essencialmente pulsional. Pulsão é o substrato motor do desejo que reclama por satisfação na efetuação da linguagem. No entanto, esta meta de satisfação é inalcançável, daí seu eterno retorno na busca por satisfação.

O Outro, portanto, não se revela por completo, dele só conhecemos o que veio à luz na expressão da linguagem. É através da mediação da linguagem que o Outro atende às demandas pulsionais, dando-lhe uma forma espaço-temporal.

O sujeito encontra-se, portanto, numa injunção existencial: só conhece quem nele atua, na efetuação da linguagem. "Desta falha, brota o desejo, um desejo sem parada, em deslocamento contínuo, pois o objeto que causa o desejo é o objeto pulsional, irremediavelmente perdido" (SANTAELLA, 2004, p. 148).

O conceito de pulsão, em Freud, está estreitamente ligado à dinâmica energética, pois é essa dinâmica a responsável por transformar o que é sentido como pressão em descarga, ou seja, em gesto expressivo. A pressão, no entanto, é da ordem do somático, é a face positiva do desejo ${ }^{8}$ e seu substrato motor, enquanto que o desejo está em nível psíquico, é sentido como algo que falta e que escapa a qualquer tentativa de completude. $\mathrm{O}$ desejo está sempre diferindo, escapando do querer consciente, tornando-o insatisfeito. $\mathrm{O}$ homem investe suas ações na tentativa de suprir este algo que falta, e é aí que os processos energéticos se evidenciam, dando forma (representação) à pulsão desejante (BRASILIENSE JÚNIOR, 1999).

Se o sujeito do desejo é movido por uma falta intangível que o mobiliza na tentativa de dar conta desta falta, a dança, por sua vez, acontece em resposta à necessidade humana de criar linguagens que atendam a essa falta pulsante.

A dança, portanto, - se observada sob o olhar freudiano - é uma possibilidade de fruição da energia pulsional. Todavia, sua efetuação figura não mais que uma possibilidade de representação da pulsão.

\footnotetext{
${ }^{8}$ Freud nunca estruturou uma teoria do desejo usando o termo em si, embora não falasse de outra coisa senão do desejo (como querer inconsciente, fora do alcance do querer consciente). É Lacan quem faz uso desse termo para situar sua releitura de Freud (BRASILIENSE JÚNIOR, 1999, p. 115)

Wovimento, Porto Alegre, v. 15, n. 03, p. 333-354, julho/setembro de 2009.
} 
Isto porque a pulsão não se apresenta, não temos referências de sua existência. Dela só conhecemos o que vem como efeito na linguagem (BRASILIENSE JÚNIOR, 1999).

A representação é uma forma de subjugar a pulsão, como recurso para poder dominá-la. O resultado da subjugação da pulsão dá origem a um representante, que pode ser a ideia (Vorstellung), ou o afeto $(A f f e k t)$. Os afetos dão a qualidade funcional aos representantes ideacionais (a ideia), ou seja, os afetos dizem respeito à qualidade do que vem a luz como representante da pulsão (BRASILIENSE JÚNIOR, 1999).

Quando se trabalha com as diferentes qualidades de energias expressivas, se trabalha com as diferentes expressões dos afetos no espaço cênico. O fluxo da energia afetiva é o que transforma a potencia nervosa e muscular em qualidade expressiva, dando o tom ao que está sendo enunciado na atuação.

\section{AANGÚSTIA: PROCESSO DE CRIAÇÃO}

Na dança, verifica-se uma energia corporal observável, mas não mensurável, que seria o representante da pulsão (os afetos). Esta energia sustenta a luminosidade do gesto. $\mathrm{O}$ que nos faz pensar que sua atuação é desejante é o fato de que, nós dançarinos, não nos contentamos com uma dança. Cada dança alimenta a vontade de mais dança, de mais movimento. Esta sensação fica evidente no momento do processo criativo. Somos tomados por uma quantidade imensa de imagens que atravessam nosso corpo em forma de movimento, sem que tenhamos um controle consciente desta projeção. A expressão foge às restrições do querer consciente e emerge a revelia desta deliberação.

Esta efetuação, no entanto, é da ordem do representativo, ou seja, faz referência a algo que pulsa dentro do corpo e que se mobiliza em direção a uma descarga através da dança. Todavia, o investimento, em resposta ao pulsar, deixa sempre um resto indicando a insuficiência de qualquer investimento na satisfação deste pulso. É aí que sinaliza a angústia, aquele sentimento de aperto que nos consome em

Movimento, Porto Alegre, v. 15, n. 03, p. 333-354, julho/setembro de 2009. 
meio à criação, atraindo todas as energias para este processo, sem, com isso, conseguir sanar a falta que nos acomete. Esta injunção mantém intocável o desejo, e alimenta o processo criativo, na medida em que o criador é afetado por esta angústia cortante.

A angústia é o sentimento que nos toma quando somos surpreendidos por algo estranho que vem à luz na experimentação, mas que deveria estar oculto nas brumas da inconsciência. Este estranho sempre retorna, inapreensível, pois nenhuma representação o subjuga, caracterizando-se aí a constância da pulsão.

Assim argumenta Cesarotto:

As sensações de aperto, de sufoco, de nó na garganta decorrem do fechamento somático dos interstícios simbólicos da subjetividade, que tira o ar. O máximo de estranhamento vem da certeza de ser possível a impossibilidade de se achar uma saída. (CESAROTTO, 1996, p. 125).

A cada novo retorno do estranho, no entanto, novas imagens são suscitadas no corpo, na tentativa de dar conta desta sensação invasiva expressa em meio ao sentimento de angústia. E, aqui, tomo a liberdade de dar meu acréscimo: este investimento alimenta o processo de criação, pois "a fonte da angústia não seca jamais" (CESAROTTO, 1996, p. 127).

Freud identifica na concomitância desse sentimento de angústia com a sensação de estranheza um traço de comportamento por ele denominado compulsão à repetição (BRASILIENSE JÚNIOR, 1999).

Quando nos entregamos à experimentação do processo criativo, algo similar acontece, alguns movimentos retornam e se repetem, e não sabemos bem o porquê deste retorno. É como se sua apresentação, num dado momento não tenha sido suficiente para dar conta de tudo o que, através daquele gesto, deveria ser expresso, daí seu retorno. Não seria este um indicativo da impossibilidade de plena satisfação da pulsão?

E o mais interessante é que cada novo retorno desta imagem/ gesto traz consigo novos arranjos gestuais no linear coreográfico,

Movimento, Porto Alegre, v. 15, n. 03, p. 333-354, julho/setembro de 2009. 
como se cada frase de movimento expressasse uma perspectiva de visão daquela imagem inapreensível.

A imagem/gesto pode ser uma célula de movimento, ou mesmo uma frase (composta por várias células). Seu caráter compulsivo, às vezes, é tão intenso que a pesquisa corporal desta imagem/gesto pode, por si só, motivar o processo criativo e a produção coreográfica. Este processo, portanto é marcado pela tensão em querer dizer, através da dança, sem encontrar, enfim, um dizer que satisfaça plenamente este querer.

Há na angústia uma tensão entre a possibilidade - que quer colocar-se como síntese na realidade - e a liberdade - que não quer se dobrar à síntese, frente à diversidade infinita dos possíveis ${ }^{9}$. Esta tensão traz inquietação e desassossego, que são as marcas da angústia. Assim, a angústia seria a atitude limite diante da eclosão da possibilidade, que faz eclipsar a liberdade em seu esforço de evitar a síntese.

A dança é o processo dessa tensão. A liberdade insiste mesmo com a eminência da síntese e é esta abertura que dá margem à criação. Quando a possibilidade eclode como evento, se dá aí sua apresentação, mas algo escapa, prometendo dizer mais se for expressa de outra maneira (as infinitas possibilidades não eventuais). A cada novo investimento, no entanto, o mesmo porém acossa, reabrindo constantemente o processo criativo. Esta injunção abre um furo na obra de arte que impede de vê-la como produto, mas como algo em constante processo.

Desta maneira, a angústia que envolve o processo criativo, mobiliza o escoamento de imagens/gestos como recurso de linguagem que dê projeção à energia da criação. Nesta dinâmica, o processo criativo nunca se esgota e está sempre disposto a se re-abrir frente ao

\footnotetext{
${ }^{9} \mathrm{~A}$ relação de tensão entre possibilidade e liberdade na angústia foi conceituada pelo filósofo Soren Aabye Kierkegaard (1813-1855). As reflexões sobre a angústia presentes neste texto estão baseadas nos estudos sobre Angústia realizados quando participei como ouvinte da " $V$ Jornada Corpolinguagem - Angústia: o afeto que não engana", evento promovido pelo grupo "Sema-Soma", do Instituto de Estudos da Linguagem (IEL) de 19 a 21 de outubro de 2005, na Unicamp. Especialmente sobre a angústia em Kierkegaard, foi fundamental as anotações realizadas durante a palestra ministrada pela Profa. Dr ${ }^{a}$. Silvia Saviano Sampaio, do Depto. de Filosofia da PUC de São Paulo (sessão plenária: Kierkegaard e a psicossomática).

Movimento, Porto Alegre, v. 15, n. 03, p. 333-354, julho/setembro de 2009.
} 
desarranjo que instiga a constante re-escrita da dança, nas infinitas possibilidades do itinerário gestual.

Este eterno retorno ao processo nos leva ao problema que estimulou a pesquisa: se é na intensidade de sentidos em curso neste eterno retorno que o corpo se abre a sua dimensão criativa de ser, não estaria aí o grande gerador de ensino e aprendizado, uma vez que é somente aí - nos domínios do processo criativo - que o corpo se deixa afetar em profundidade?

\section{CONSIDERAÇõES FINAIS}

Toda esta discussão sobre a performance na dança, a diferença entre graus ativos de energia numa atuação, o curso intempestivo da composição em dança e o traço furtivo do Outro nas relações em ato, querem chamar a atenção para uma outra perspectiva da educação corporal. Quando se analisa estas prerrogativas de criação gestual, abrem-se as dimensões do processamento criativo e é aí que arte e educação encontram infinitas possibilidades de diálogo. Todavia, tal diálogo só é possível neste deslocamento do olhar, que considera a educação como um processo criativo.

Através do processo criativo, o corpo constrói para si sentidos no curso daquilo que lhe afeta em profundidade, nos domínios da sensibilidade. $\mathrm{O}$ que o afeta no mundo e em si mesmo é o grande regente de seu processo educacional estético. Sem esta atuação potencial, o corpo não passaria de uma máquina regrada, alienada por imperativos descorporificados, postos sobre o corpo como malha condicionante. Neste mal entendido da atuação corporal, as convenções e os determinismos sociais são priorizados em detrimento da potência criativa, daí a percepção da educação no corpo como um processo de aquisição mecânica de conhecimento. O processo criativo, no entanto, inverte este processo, proclamando o poder do corpo como agente atuante e fundamental do processo educacional. Assim sendo, a educação é algo que emerge do corpo, na medida em que ele se deixa afetar.

Tal deslocamento, no entanto, só é possível quando se mexe na perspectiva educacional. Antes de traçar de fins à serem alcançados,

Movimento, Porto Alegre, v. 15, n. 03, p. 333-354, julho/setembro de 2009. 
o próprio processo educativo deve se reconhecer como um fim em si mesmo. É aí que a intervenção pode ser vista como um laboratório de criação, que permite ao corpo experimentar-se ao sabor do processamento criativo. Este deslocamento não admite uma percepção dicotômica que coloca o corpo como objeto da educação. Para tanto, é preciso alterar a percepção autocontrolada, segura de si e de sua capacidade de aquisição e assimilação de conhecimento. Daí a necessidade em se trabalhar a dança no ato em que ela se faz como evento, para extrair daí, ou melhor, para se trabalhar aí, a furtiva percepção corporal que lhe é própria, campo fértil de sensibilização e de educação estética.

A percepção corporal no momento em que a dança é ato, faz surgir um atuante elíptico de si mesmo, agente potencial de criações, na vazão da espontaneidade. A partir deste processo espontâneo, o artista faz sua arte, ao mesmo tempo em que contorna um processo educativo estético nas vias desta atuação. Visto sob esta perspectiva, a educação através das artes corporais só pode ser concebida num duplo movimento do olhar: ao mesmo tempo em que se projeta na vazão de sua espontaneidade, vai se constituindo, como unidade objetal - passível de ser verificada como objeto de conhecimento, no enquadramento daquilo que insistimos chamar de técnica corporal.

As negociações sobre esta criação podem favorecer a espontaneidade - no caso da arte performática - ou o contorno desta unidade - a estrutura léxica constitutiva do código (a forma do gesto). Quem faz a mediação desta negociação é o processo criativo. É através dele que o artista trabalha a forma do movimento como material em constante re-constituição formal. Daí o eterno retorno do processo, como recurso para dar vida à forma, uma vez que esta tende inevitavelmente a uma estrutura ausente, inóspita de saber e sentidos.

A dança, portanto, não está na estrutura linear de sua composição gestual, mas na dinâmica que força à transformação deste linear, nas intensidades em curso em meio à atuação. Visto sob esse olhar, não há atuante nem técnica corporal se estes não forem observados nas relações em ato. É impossível verificar justamente suas

Movimento, Porto Alegre, v. 15, n. 03, p. 333-354, julho/setembro de 2009. 
marcas, isto é, aquilo que figura como técnica corporal, sem que esta seja plena dinâmica relacional.

O processo criativo, na dança, inaugura um novo olhar sobre o itinerário do corpo. Como o corpo organiza seu fazer? O curso deste processo revela uma metodologia que não é dada a priori como meio previamente estruturado, mas como fim provisório, a cada novo investimento criativo. Assim, a inscrita do método está sempre por vir nos campos de intensidade e sentidos eventualmente experimentados. É no curso destas relações eventuais, na regência da angústia, do desejo, da vontade de expressão e transformação que o corpo vai traçando seus caminhos e apreendendo uma linguagem corporal, trabalhando-a ao sabor de suas necessidades de expressão.

O processo criativo na dança, portanto, pode ser considerado como um processo educativo estético, pois permite ao dançarino possibilidades de trabalhar a técnica corporal não como algo posto $\mathrm{e}$ imposto frente à passividade alienante de um corpo adestrado, mas como um agente potencial de criação da linguagem corporal, no traço espontâneo do processamento criativo. Sob este olhar, a técnica corporal não é um objeto e/ou objetivo a ser alcançado, mas o próprio atuante furtivo em curso nos laboratórios de experimentação.

Sob esse mesmo olhar, pode-se verificar o processo educativo. A cada novo investimento da atuação criativa, a dança eleva os níveis de ensino e aprendizado a novos patamares. Como efeito da intervenção educativa, não vemos a atuação em si, mas os resultados - os patamares - em que o corpo em processo educativo se encontra. Todavia, aí não está o processo educativo, senão no seu traço especular, isto é, no traço mínimo possível para se prever sua evolução. Sendo assim, a educação - se a considerarmos como o processo que afeta o corpo - só pode ser justamente verificada no traço do atuante furtivo, em vigor na vazão da espontaneidade, nos laboratórios de criação. É aí que a educação se confunde com os caminhos da dança, inspirando os educadores a novos olhares sobre seu campo de conhecimento e sobre os modos a partir dos quais este conhecimento é disseminado no processo educativo.

Os processos criativos na dança nos alertam para a necessidade de abrir caminho na educação para a busca da sensibilização corporal

Movimento, Porto Alegre, v. 15, n. 03, p. 333-354, julho/setembro de 2009. 
no traço de um Outro em cena. Só então o corpo é capaz de estruturar seu caminho, sua técnica, no curso de sua própria interação com a linguagem corporal. É na vazão destes domínios, por vir em meio ao processo, que o corpo descobre o que lhe afeta, tomando para si o aprendizado de uma linguagem corporal, para efetuá-la no curso original de seus próprios desejos.

The dance (on) stage(s) the Other: prerogatives
for an aesthetic education through the creative
process
Abstract: The dance installs in the body another scene
of senses that raises the creative performance and
not that can be speculated about it. There, "who dan-
ce" is the Other one, making the body acting of another
manner, beyond the systemic contour of Ego. Without
the presence of this forged performance, the body would
not pass of one ruled machine in function of something
and not in favor of himself, as original movement of him-
self. This article intends to make a reflection about the
corporal perception in the dance, trying to point out the
creative performance. So, we opened a way to under-
stand the process creative as field of corporal sensiti-
zation where the educative intervention is accompli-
shed in the body.
Keywords: Dancing. Kinesics. Psychoanalysis.
Creativeness.

La danza "en cena" el Otro: prerrogativas para
una educación estética con el proceso creativo
Resumen: La danza instala en el cuerpo otra escena
de sentidos que levanta el funcionamiento creativo y
no que se puede especular sobre él. Allí, "quién dan-
ça" es el Otro, haciendo el cuerpo actuar de otra manera,
más allá del contorno sistémico del Ego. Sin la presen-
cia de este funcionamiento forjado, el cuerpo no paso
de una máquina gobernada en función de algo y no a
favor de él, como movimiento original de él mismo.
Este artículo se prepone hacer una reflexión sobre la
percepcion corporal en la danza, intentando precisar
el funcionamiento creativo. Así pues, abrimos una manera
de entender el proceso creativo como campo de la
sensibilización corporal donde la intervención educativa
se logra en el cuerpo.
Palabras clave: Baile. Cinésica. Psicoanálisis. Criati-
vidad.

Movimento, Porto Alegre, v. 15, n. 03, p. 333-354, julho/setembro de 2009. 


\section{Antigor Originais}

Flávio Soares Alves

\section{REFERÊNCIAS}

BRASILIENSE, L. S. O desejo da psicanálise. Porto Alegre: Sulina, 1999.

BRITTO, A. B. O inconsciente no processo criativo do ator: por uma cena dos sentidos. Dissertação (Mestrado).- Escola de Comunicação e Artes da USP. São Paulo, 2001.

CESAROTTO, O. No olho do Outro. São Paulo: lluminuras, 1996.

COHEN, R. Performance como linguagem: criação de um espaço-tempo de experimentação. São Paulo: Perspectiva, USP, 1989.

DEVEREUX, O. Xamanismo e as linhas misteriosas. Lisboa: Estampa, 1993

JUNG, G. C. O Espírito da Arte e na Ciência. Petrópolis, RJ: Vozes, 1991.

KATZ, H. Com sofisticação, Cena 11 investiga o movimento. In: O Estado de São Paulo, São Paulo, Caderno 2. Dança Crítica; 6 jul. 2005.

LACAN, J. Escritos. Tradução de Vera Ribeiro. Rio de Janeiro: Jorge Zahar, 1978.

NIETZSCHE, F. Trechos escolhidos. São Paulo: Abril Cultural, 1974. (Coleção Os Pensadores).

PIGNATARI, D. O que é comunicação poética. Cotia: Ateliê, 2004

SANTAELLA, L. Corpo e Comunicação: sintoma da cultura. São Paulo: Paulus, 2004.

SOARES, M. V. Técnica Energética: fundamentos corporais de expressão e movimento criativo. Tese (Doutorado). Instituto de Artes. Campinas: Universidade Estadual de Campinas, 2000.

Recebido em: 16.08.2008

Aprovado em: 17.02.2009

Movimento, Porto Alegre, v. 15, n. 03, p. 333-354, julho/setembro de 2009. 